УДК 341.9

DOI https://doi.org/10.32837/apdp.v0i87.2808

\title{
О.С.Овечкіна
}

\section{ВИРІШЕННЯ КОЛІЗІЙНИХ ПИТАНЬ ПРАВОВОГО СТАТУСУ ЮРИДИЧНИХ ОСІБ У ЗАКОНОДАВСТВІ ФРН: СУЧАСНИЙ СТАН ТА ПЕРСПЕКТИВИ}

Постановка проблеми. Розвиток транскордонних економічних відносин, міжнародної торгівлі зумовлюють здійснення діяльності юридичними особами на територіях різних держав. Для «приймаючої» держави щодо діяльності іноземної юридичної особи постає необхідність вирішення низки юридичних питань, зокрема, щодо правового статусу, яким чином здійснювати регулювання правовідносин таких юридичних осіб з іншими суб'єктами права та безліч інших. Юридична особа може бути створена в одній країні, здійснювати діяльність або мати місцезнаходження в інших; учасниками цієї юридичної особи можуть бути фізичні особи з різним громадянством, акціонерами виступати юридичні особи різної державної належності тощо, через що може стати наслідком неоднакова кваліфікація одних і тих самих дій суб’єктів права та правовідносин, в яких беруть учать останні. У зв’язку із цим постають питання: право якої держави підлягає застосуванню під час установлення правового статусу іноземної юридичної особи, за допомогою яких критеріїв віднайти правовий зв’язок з компетентним правопорядком з метою регулювання питань правового статусу іноземної юридичної особи.

Вирішення питання регулювання приватно-правого статусу юридичних осіб у науці міжнародного приватного права вже традиційно вважають одним із найскладніших, оскільки правові системи держав містять суттєві відмінності в обсязі правоздатності юридичних осіб, регламентації щодо порядку їх створення та функціонування, що призводить до правових колізій.

Актуальність дослідження регулювання приватноправового статусу іноземних юридичних осіб у ФРН зумовлюється тим, що юридичні особи України вже традиційно співпрацюють з юридичними особами ФРН, яка є одним із найбільших торгових партнерів України. Крім того, німецька економіка натепер є найпотужнішою економікою серед держав-членів Свропейського Союзу.

Вказані обставини зумовлюють необхідність вивчення різноманітних аспектів правового регулювання статусу та діяльності юридичних осіб в ФРН, зокрема теорії та практики вирішення колізійних проблем, що виникають під час визначення правового статусу іноземної юридичної особи. Враховуючи специфіку правової системи СС, аналіз вказаної проблеми та можливих шляхів її подолання потребує досліджень, що враховують останні тенденції та зміни зазначеного регулювання як національним законодавством $Ф Р Н$, так і правом $€ C$.

Мета дослідження - розглянути особливості колізійно-правового регулювання статусу юридичних осіб у ФРН, а також дослідити вплив права ЄС на національне колізійне регулювання правого статусу юридичних осіб державами-членами ЄС (на прикладі ФРН). 
Виклад основного матеріалу. Правове регулювання відносин з іноземним елементом зумовлюється вирішенням проблем розбіжностей у матеріальному цивільному законодавстві різних держав правових норм. У міжнародному приватному праві (далі - МПрП) для подолання суперечностей та конкуренції правових норм використовують колізійний метод регулювання, завданням якого є визначення того, право якої держави підлягає застосуванню.

У МПрП виокремлюють низку критеріїв, на основі яких визначається належність іноземної юридичної особи до права певної держави. Так, у МПрП історично сформовано чотири теорії (доктрини): теорію інкорпорації, теорію осілості, теорію центра здійснення основної діяльності або центру експлуатації, теорію контролю. «Теорії, законодавству і правозастосувальній практиці відомі декілька доктрин і, відповідно, критеріїв визначення «національності» юридичних осіб, які можна вважати традиційними. Це теорія: інкорпорації (критерій заснування чи реєстрації); осілості («ефективного місцеперебування», тобто місцезнаходження головних органів юридичної особи - адміністративного центру, центру управління тощо); центру експлуатації (місця, де відбувається основна виробнича, комерційна чи інша діяльність), а також контролю, яка виникла з метою виявлення «ворожих іноземців» у разі встановлення «національності» юридичних осіб під час ведення воєнних дій» [1, с. 112].

$\mathrm{y}$ країнах-членах $\mathrm{CC}$ щодо визначення правового статусу юридичних осіб переважно застосовується дві колізійно-правові теорії - теорія осілості та теорія інкорпорації. Так, у державах-членах ЄC «по-різному визначається національність юридичної особи, в деяких державах - за місцем реєстрації компанії, в інших за місцем ведення основної підприємницької діяльності...» [2, с. 324].

Згідно з теорією інкорпорації (нім. Gr ndungstheorie, англ. incorporationtheory) належність юридичної особи до права певної держави визначається на основі акта про наділення правоздатністю юридичної особи, тобто на території якої держави заснована юридична особа або зареєстровано її статутні документи. Вказана теорія застосовується в таких країнах, як Чехія, Данія, Швеція, Фінляндія, Нідерланди, Ірландія та інших.

Теорія осілості (нім. Sitztheorie, англ. siagesocial) встановлює належність юридичної особи до права певної держави за допомогою критерію функціонування головного органу управління юридичної особи (наприклад, рада директорів, правління, інші виконавчі органи). При цьому виокремлюють два види теорії осілості: статутну (формальну), що визначена в уставному документі юридичної особи (наприклад, Іспанія, Румунія), та ефективну (реальну), що передбачає врахування фактичного місцезнаходження центру управління юридичної особи (наприклад, ФРН, Португалія, Австрія, Греція).

Переваги застосування теорії осілості полягають у мінімізації можливостей обходу закону або зловживанням правом юридичними особами у зв'язку з тим, що законодавством деяких країн передбачено менш жорсткі вимоги щодо реєстрації, статутного капіталу, податкових зобов'язань, захисту прав працівників компанії тощо. Однак суттєвий недолік застосування цієї теорії полягає в унеможливленні переміщення місцезнаходження правління юридичної особи з однієї держави в іншу, оскільки переміщення адміністративного центру матиме наслідком втрату 
правосуб'єктності юридичної особи в «приймаючій» державі та невизнання іï, а також, відповідно, необхідність створення юридичної особи згідно із законодавством держави, на території якої розташовані органи правління юридичної особи.

Ввідний закон до Німецького цивільного уложення (Einführungsgesetz zum Brügerliches Gesetzbuch, EGBGB) не містить колізійної норми (Anknüpfungspunkte), що визначає правовий статус юридичної особи. Натомість на доктринальному рівні та в судовій практиці німецьких судів, починаючи з початку XIX ст., закріплено критерій фактичного (реального) місцезнаходження в разі встановлення особистого закону юридичної особи. Відповідно до § 24 Німецького Цивільного Уложення (Bürgerliches Gesetzbuch, BGB) [3] поняття «місцезнаходження» організації (sitz) це місце здійснення її управління, якщо не вказано інше. Проте EGBGB не містить положень, як розуміти «місцезнаходження» компанії (Sitz der Gesellschaft) у разі встановлення її національної приналежності та, відповідно, встановлення особистого закону юридичної особи. Відсутня норма і щодо визначення «особистого закону» (Personalstatut der juristischen Person) або «особистого статуту» (Gesellschaftsstatut) юридичної особи. BGB регулює лише загальні питання, що пов'язані з діяльністю юридичної особи, зокрема, загальні правила створення, організації та ліквідації юридичної особи, а також щодо діяльності окремих видів некомерційних організацій та організацій публічного права (Книга 1, ч. 1, розд. 2 BGB).

Разом із тим німецьким правом передбачено створення товариств з персональною відповідальністю учасників (Personengesellschaften) та товариств із залученим капіталом (Kapitalgesellshaft). До товариств з персональною відповідальністю належать товариство цивільного права (Gesellschaft b rgerlichen Rechts, GbR), відкрите торгове товариство (Offene Handelsgesellschaft, OHG), командитне товариство (Kommanditgesellschaft, KG). Капітальні товариства (Kapitalgesellshaft) або корпорації засновані на об’єднанні капіталу учасників, здебільшого з економічною метою, діяльність капітальних товариств регулюється Торговим кодекcoм (Handelsgesetzbuch, HGB) (розділ 2 книга третя) та передбачає обов'язково формування статутного капіталу та реєстрацію компанії в Торговому реєстрі (Handelsregister).

У ФРН можлива діяльність капітальних компаній у формі товариства з обмеженою відповідальністю (GmbH), спрощеної форми товариства з обмеженою відповідальністю - підприємницького товариства з обмеженою відповідальністю (mini $\mathrm{GmbH}$, Unternehmergesellschaft haftungsbeschränkt, UG), акціонерного товариства (Aktiengellschaft, AG), командитного товариства в акціях (KGaA).

Найпоширенішою організаційно-правовою формою у ФРН є товариство з обмеженою відповідальністю (Gesellschaften mit beschränkter Haftung, GmbHG), чия діяльність регулюється Законом про товариства з обмеженою відповідальністю 1892 року (Gesetz betreffend die Gesellschaften mit beschränkter Haftung, GmbHG) та Торговим кодексом Німеччини (§ 238-342a). Із прийняттям Закону про боротьбу зі зловживаннями та модернізації закону про ТОВ (Gesetz zur Modernisierung des GmbH-Rechts und zur Bekämpfung von Missbr uchen, MoMiG) запроваджено можливість спрощеної форми ТОВ - підприємницької компанії (Unternehmergesellschaft haftungsbeschränkt). 
Створення $\mathrm{GmbH}$ передбачає підписання учасниками (або єдиним учасником) та нотаріальне посвідчення установчого договору/статуту і передачу пакету документів реєстраційному органу - місцевому суду відповідно до запланованого місцезнаходження товариства. Товариство вважається створеним з моменту внесення відповідного запису в Торговий реєстр місцевим судом (судом першої інстанції (Amtsgericht), на який покладено функції ведення та правового забезпечення Торгового реєстру.

Місцезнаходження компанії (Sitz der Gesellschaft) має бути зазначено в статуті (Satzungssitz) та мати розташування на території ФРН. У § 57 Німецького Цивільного Уложення [3] щодо мінімальних вимог до статуту асоціації зазначено, що статут повинен містити мету, назву і місцезнаходження асоціації та вказувати, що асоціація має бути зареєстрована.

Під статутним місцезнаходженням юридичної особи (Satzungssitz) розуміється місцезнаходження офісу компанії, який зазначено в статуті або угоді про товариство. Згідно з 7 Закону про товариства з обмеженою відповідальністю (Gesetz betreffend die Gesellschaften mit beschränkter Haftung, GmbHG) [4] компанія повинна бути зареєстрована в суді, в окрузі якого вона має місце реєстрації, для внесення до комерційного реєстру. Відповідно до § 17 Німецького цивільного процесуального кодексу (Zivilprozessordnung, ZPO) [5] «загальне місце юрисдикції $<$...> корпорацій, компаній, кооперативів <...>, на які можуть бути подані позови як такі, визначається місцем їх знаходження. Якщо не вказано інше, місцезнаходженням є місце, де розміщується адміністрація».

Німецьким правом адміністративний орган правління (Verwaltungssitz) розуміється як місце розташування адміністративного (головного) офісу юридичної особи, тобто реальне (ефективне) місцезнаходження органів управління юридичної особи, центр, з якого здійснюється керівництво та приймаються рішення.

Критерій осілості у ФРН застосовується згідно із принципом дії двосторонньої колізійної норми. Це означає, що критерій осілості застосовується щодо юридичних осіб, які мають реальне місцезнаходження як у ФРН, так і щодо юридичних осіб, які мають місцезнаходження в інших державах.

Як уже зазначалось, згідно з теорією осілості переміщення органів правління з однієї держави в іншу не видається можливим. Так, якщо юридична особа, створена за законодавством ФРН і з місцезнаходженням їі органів правління теж у ФРН, має намір перемістити органи правління в іншу державу без відповідних змін у статуті, то суд, що здійснює реєстрацію товариств, у ФРН прийме рішення про припинення діяльності такої юридичної особи та ії̈ ліквідацію. Або якщо іноземна юридична особа, яка створена в іншій державі, здійснює переміщення органів правління у ФРН із відповідними змінами в статуті, не матиме правосуб'єктність у ФРН. Це означає, що така іноземна юридична особа має пройти процедуру ліквідації в державі створення, скласти статут у новій редакції та зареєструвати юридичну особу згідно з нормами законодавства ФРН. У такому разі особистий закон цієї юридичної особи буде встановлюватись німецьким законодавством.

Згідно з німецьким правом саме реальне місцезнаходження органів правління юридичної особи є тим юридичним фактом, який пов'язує юридичну особу з держа- 
вою під час вирішення питань визначення її правового статусу, тим самим $є$ необхідною умовою щодо отримання чи збереження правосуб'єктності цієї юридичної особи, якщо вона має намір здійснювати діяльність у ФРН. У даному випадку можливі виключення в разі укладання міжнародного договору між ФРН та державами щодо вирішення таких питань в інший спосіб.

Наприклад, статтею 25 пунктом 5 Договору між ФРН та США про дружбу, торгівлю та судноплавство передбачено, що «організації, які створені відповідно до законів та інших нормативних актів однієї з договірних сторін на її території, вважаються компаніями цієї договірної сторони; їхній правовий статус визнається на території іншої договірної сторони» [6].

Слід зауважити, що з поглибленням інтеграційних процесів європейських країн та створенням ЄС вирішення питань правового статусу іноземних юридичних осіб набуло більш високого ступеня актуалізації, що зумовлюється специфікою правопорядку ЄС. Установчі документи ЄС, а саме статті 49 та 54 Договору про функціонування Свропейського Союзу (ДФЕС), визначають свободу заснування та економічної діяльності компаній [7], відповідно до яких створення юридичної особи має здійснюватися на умовах, що визначаються законодавством країни для власних громадян та у відповідності з положеннями глави щодо безперешкодного руху капіталів.

Таким чином, застосування теорії осілості, яка зазвичай передбачає збіг фактичного та статутного місцезнаходження юридичної особи, суперечить змісту принципу свободи заснування та економічної діяльності. Це пов’язано з тим, що юридична особа, здійснюючи діяльність у державі, що використовує критерій осілості, та маючи заснування в іншій державі, не визнаватиметься як учасник правовідносин та не матиме правосуб'єктності в приймаючій державі, поки не буде пройдено процедуру ліквідації в державі заснування та створення «заново» юридичної особи в приймаючій державі відповідно до норм її законодавства.

Слід зазначити, що в ЄС з метою подолання проблем, які пов' язані з відсутністю одноманітного регулювання правового статусу юридичних осіб та забезпечення безперешкодного функціонування Єдиного ринку, запроваджено нові організаційно-правові форми юридичних осіб - європейську компанію (Societas Europaea), європейський кооператив (Societas Cooperative Europaea), європейське об'єднання за економічними інтересами (European Economic Interest Grouping). Свропейською комісією розробляються проекти щодо таких нових форм, як європейська приватна компанія, європейська асоціація, європейське товариство взаємодопомоги. Діяльність таких форм юридичних осіб в $Є С$ є своєрідною альтернативою колізійному способу подолання проблем визначення правового статусу юридичних осіб та долає частково зазначені вище проблемні питання (наприклад, визнання країнами-членам ЄС правосуб'єктності європейської компанії, можливості спрощення організаційної структури та можливості переміщення 3-поміж країн-членів ЄС без ліквідації цієї компанії в країні заснування та ін.).

Крім того, одним зі способів розв'язання проблеми відсутності єдиного правового регулювання питань діяльності юридичних осіб в ЄС є видання директив, що зобов’язує державу-члена ЄС внести зміни до національного законодавства. Так, інституціями ЄС було заплановано ухвалення п'ятнадцяти директив щодо різних 
питань правового статусу та діяльності юридичних осіб, проте внаслідок значних розбіжностей у національних законодавствах держав-членів тільки 11 з них набули чинності. Із прийняттям Чотирнадцятої директиви щодо переміщення місцезнаходження компаній стало б можливим вирішення питання щодо своєрідного компромісу застосування теорій осілості та інкорпорації, однак проєкт вказаної директиви не був схвалений у зв'язку з відсутністю узгодженої позиції держав-членів щодо багатьох її положень.

14.06.2017 р. прийнято Директиву 2017/1132 Європейського парламенту та Ради ЄС щодо певних аспектів законодавства про товариства, яка є кодифікованою версією застарілих і неодноразово змінюваних інших директив (82/891/ЄЕС, 89/666/EEC, 2005/56/EC, 2009/101/EC, 2011/35/EC, 2012/30/EC). 27.11.2019 p. Європейський Парламент та Рада прийняли Директиву 2019/2121 про транскордонні перетворення, злиття та поділи [8], що вносить зміни до Директиви 2017/1132. Директива 2019 р. набула чинності з 01.01 .2020 р., держави-члени мають привести національні законодавства у відповідність до Директиви до 31.01.2023 р. Вказана Директива уточнює правила про транскордонне злиття в межах ЄС та вперше вводить правила щодо транскордонного перетворення та поділу товариств з обмеженою відповідальністю для всіх держав-членів. Директива включає можливість прискорення процедури щодо всіх трьох транскордонних операцій, а перевага схеми «конвертації» в тому, що компанія зберігає правосуб'єктність у приймаючій державі (включно з активами, зобов'язаннями, зокрема угодами, що укладені в державі створення компанією). При цьому статутне місцезнаходження змінюється та має бути в приймаючій державі, реальне місцезнаходження має збігатися зі статутним місцезнаходженням (у державах, де застосовується критерій осілості). Директива 2019/2121 містить положення щодо «перевірки проти зловживань». Так, якщо компетентний орган вважає, що транскордонна операція може бути використана для зловживання, шахрайства чи злочинних цілей, у компетентного органу буде додатково три місяці для подальшої оцінки. Така оцінка може включати вимогу незалежного експертного звіту. Головною перевагою Директиви $2019 / 2121 \epsilon$ те, що вона забезпечує майже ідентичний процес для трьох транскордонних операцій на всій території ЄС. Однак слід зазначити, що директиви визначають, якого результату правового регулювання має бути досягнуто, при цьому форми та методи, що застосовуються для досягнення таких результатів, мають бути вибрані державою-членом на власний розсуд.

Особливе значення в процесах регулювання питань, що пов'язані з правовим статусом юридичних осіб, мають рішення Суду ЄС. Суд ЄС уточнює та здійснює тлумачення законодавства ЄС, що у свою чергу допомагає вирішенню колізій та подоланню суперечностей між норами права ЄС та положеннями національних законодавств держав-членів. Рішення Суду ЄС роз'яснюють, коли держави-члени порушують законодавство ЄС, а також те, як необхідно тлумачити і застосовувати норми права ЄС на національному рівні. Суд ЄС рішеннями в таких справах, як «Daily Mail», «Centros», «berseering», «Inspire Art», «Sevic», «Cartesio», «Vale ptsi kft.», «National Grid Indus», «Polbud», серед іншого, розглядав питання законодавчих перешкод під час переміщення компаній, у зв'язку з чим 
Судом ЄС необхідно було здійснити тлумачення принципу «свободи заснування та економічної діяльності», які межі цієї «свободи», що міститься в установчих договорах $\mathrm{C}$ тощо.

Судом $\mathrm{CC} \mathrm{у} \mathrm{справі} \mathrm{«Centros»} \mathrm{[9]} \mathrm{розглядалась} \mathrm{правомірність} \mathrm{рішення} \mathrm{про} \mathrm{відмову}$ Міністерства торгівлі Данії в реєстрації філіалу компанії «Centros Ltd.», яка створена у Великобританії двома датськими громадянами, не здійснюючи жодної діяльності в державі заснування. Позиція датської сторони полягала в тому, що створення компанії «Centros Ltd.» за англійським правом є «обходом» закону, а саме датського законодавства в частині мінімального розміру статутного капіталу, через штучну реєстрацію за англійським правом товариства з обмеженою відповідальністю (privat limited company), де відсутні аналогічні вимоги для створення компанії. На думку датської сторони, справжні наміри засновників - не відкриття філії в Данії, а «первинне» заснування юридичної особи - відкриття штаб-квартири (головного органу правління), оскільки жодної господарської діяльності з моменту iї створення у Великобританії не здійснювалось, до того ж діяльність на території Данії «Centros Ltd.» призвела би до порушень прав кредиторів цієї компанії.

Суд ЄС постановив, що відмова в реєстрації філії є порушенням положень статей 43 та 48 ДЕС (нині статті 49 та 54 ДФЕС). Також Судом зауважено, що створення за більш ліберальними вимогами в державі-члені юридичної особи, з подальшою реєстрацією їі філії в іншій державі-члені ЄС, не є ознакою зловживання правом. Факт того, що юридична особа не здійснює жодної діяльності за місцем реєстрації та здійснює всю діяльність у державі, де створено її філіал, також не є «обходом» закону і не є підставою незастосування положень права ЄС щодо свободи заснування. Цим рішенням Суд СС порушив питання доцільності застосування критерію осілості.

У справі «Überseering» [10] Суд СС розглядав питання невизнання правосуб’єктності юридичної особи німецьким судом. Голландське ТОВ «Überseering B. V.» уклало договір будівельних робіт свого приміщення, що розташовано в Дюссельдорфі (Німеччина). У подальшому всі долі участі в ТОВ «Überseering В. V.» було придбано двома громадянами Німеччини. Через деякий час компанія звернулася до німецького суду з позовними вимогами до контрагента Північної будівельної компанії Baumanagement GmbH стосовно неналежного виконання договірних зобов'язань. Проте німецьким судом у розгляді позову було відмовлено, посилаючись на те, що з придбанням німецькими громадянами долі компанії Überseering B. V. управління іï діяльністю здійснювалось у Німеччині, відповідно, відбулось переміщення фактичного місцезнаходження юридичної особи. Оскільки в Німеччині застосовується критерій осілості, німецький суд не визнав правосуб'єктність компанії Überseering B. V., що створена за голландським правом, а фактичне місцезнаходження має в Німеччині, відповідно до права якої така юридична особа має пройти процедуру ліквідації в Голландії та створення за німецьким законодавством.

Суд ЄС, розглядаючи обставини справи, вирішив, що юридична особа, яка створена відповідно до норм законодавства держави-члена, має право здійснювати переміщення статутного або фактичного місцезнаходження в іншу державу-член ЄС без втрати її правосуб'єктності. При цьому право держави створення може міс- 
тити певні обмеження щодо правосуб'єктності такої юридичної особи в державі створення. Такі обмеження мають бути «домірними» та обгрунтовані публічними інтересами.

Слід зазначити, що у справах Centros Ltd та Überseering B. V. Судом ЄC наголошено на необхідності розроблення державами-членами норм національного законодавства, що будуть перешкоджати зловживанням правом під час заснування юридичних осіб, оскільки фактично рішення в цих справах надавало можливість формального заснування компаній у державах з найбільш ліберальними умовами ведення діяльності, що призводить до зловживань з боку компаній. Директива2019/2121міститьположення,щочасткововрегульовуютьвказаніпроблемніаспекти.

Рішенням у справі Polbud [11] Суд ЄС зазначив про можливість переміщення зареєстрованого органу правління юридичної особи поміж держав-членів ЄС у випадках, коли вказаною юридичною особою не передбачається здійснення економічної діяльності у відповідній державі. Крім того, рішенням зазначається щодо дії принципу свободи заснування, який розповсюджується стосовно всіх видів юридичних осіб, що створені на підставі норм національних законодавств держав-членів ЄС та мають зареєстрований орган правління або основне місце діяльності на території держав-членів. Таким чином, ідеться про можливість, зокрема, здійснити перетворення юридичної особи на іншу юридичну особу, що регулюється правом іншої держави-члена ЄС.

Висновки в рішеннях Суду СС містять чимало неоднозначних та суперечливих позицій у питаннях, які ним розглядались, однак їхній зміст дозволяє стверджувати про наявність тенденції щодо нівелювання значення теорії осілості в СС як колізійного способу регулювання правових відносин з іноземним елементом. Таким чином, прецедентне право Суду ЄС змінює принципи, за якими держави-члени мають вирішувати колізійні питання регулювання статусу юридичних осіб. Крім того, Суд ЄС наголошує на необхідності вирішення зазначених проблемних питань шляхом гармонізації законодавства в рамках ЄС.

Упродовж останніх років німецькі судді у своїх рішеннях, посилаючись на рішення Суду ЄС, відхиляють можливість застосування критерію осілості. Проте це стосується тих випадків, коли вирішується питання між юридичними особами, які походять із держав-членів ЄС.

Вищий регіональний суд Мюнхена рішенням від 01.07.2002 p. II ZR 380/00 визнав правоздатність за товариством з обмеженою відповідальністю (limited company), що створена за законом Нормандських островів (Великобританія), хоча вона мала реальне місцезнаходження у ФРН [12].

Вищий регіональний суд Нюрнберга рішенням від 19.06.2013 р. дозволив «транскордонну зміну» люксембурзькій компанії S. à rl на GmbH ФРН [13]. Предметом розгляду справи було внесення $\mathrm{GmbH}$ до Торгового реєстру ФРН. Компанія була заснована як Société à responsabilité limitée (S. à rl - компанія з обмеженою відповідальністю) відповідно до закону Люксембургу та зареєстрована з місцевим офісом у Люксембурзі в комерційному реєстрі Великого Герцогства Люксембург. У 2011 році обидва акціонери S. à rl провели збори акціонерів і вирішили перенести компанію та адміністративний штаб S. à rl з Люксембургу в Ерланген. Люк- 
сембурзьким нотаріусом було складено новий статут, компанію було виключено із комерційного реєстру в Люксембурзі на тій підставі, що штаб-квартира компанії була перенесена до Німеччини. Проте запит на реєстрацію в Торговому реєстрі ФРН було відхилено. Нотаріус подав скаргу на це, посилаючись на рішення ЄС у справі Vale Építési kft. Вищий регіональний суд Нюрнберга дозволив транскордонну зміну компанії.

Вищий суд Берліна в рішенні від 21.03.2016 p. (22 W 64/15) [14] стосовно допустимості транскордонної зміни юридичної форми з французької $\mathrm{GmbH}$ на німецьку $\mathrm{GmbH}$ вирішив, що це розглядається відповідно до німецького права. Товариство з обмеженою відповідальністю, засноване за французьким законодавством, мало намір збільшити статутний капітал, перенести зареєстрований офіс з Парижа до Берліна та прийняти новий статут згідно з німецьким законодавством. Однак реєстрацію цього перетворення було відхилено німецьким судом. Вищий суд Берліна вважає скаргу компанії щодо відмови прийнятною та обгрунтованою.

Вищий регіональний суд Франкфурта-на-Майні в рішенні від 03.01.2017 р. [15] постановив, що «зміна форми» німецького $\mathrm{GmbH}$ на італійську правову форму Srl є допустимою, посилаючись на рішення Суду ЄC («Sevic», «Cartesio», «Vale Építési kft.»).

Висновки. Таким чином, на доктринальному рівні та в судовій практиці німецьких судів, починаючи із початку XIX ст., закріплено критерій фактичного (реального) місцезнаходження під час встановлення особистого закону юридичної особи. Щодо іноземних юридичних осіб, які належать до країн, котрі не є державами-членами $\mathrm{CC}$, німецькими судами застосовується, як правило, критерій фактичного місцезнаходження. В ЄС застосування теорії осілості у разі визначення особистого закону (статуту) юридичної особи фактично перешкоджає реалізації принципу свободи заснування, який міститься в установчих актах ЄС, оскільки переміщення центрів управління юридичної особи на територію держави, де застосовується теорія осілості, має наслідком зміну застосовного права, а також втрату правосуб'єктності юридичної особи. Прецедентна практика Суду ЄС зумовила, серед іншого, зміни щодо визначення правового статусу юридичних осіб в СС, а саме обмеження застосування теорії осілості, про що засвідчує практика німецьких судів. У зв’язку з відсутністю одноманітних підходів щодо правового регулювання статусу юридичних осіб ЄС долає вказані питання шляхом здійснення гармонізації національних законодавств держав-членів ЄС з окремих питань правового статусу та діяльності юридичних осіб, а також створенням нових організаційно-правових форм юридичних осіб, правовий статус та діяльність яких регулюється правом ЄС.

\section{Jimepamypa}

1. Фединяк Г.С., Л.С. Фединяк Л.С. Міжнародне приватне право : підручник. 4-те вид., перероб і допов. Київ : Атіка, 2009, 500 с.

2. Європейське право : Право Європейського Союзу : підручник. У трьох книгах / за заг. ред. B.I. Муравйова. Київ : Ін. юре, 2015, Книга 2.456 с.

3. B rgerliches Gesetzbuch. URL: https://www.gesetze-im-internet.de/bgb/

4. Gesetz betreffend die Gesellschaften mit beschr nkter Haftung. URL: https://www.gesetzeim-internet.de/gmbhg/ 
5. Zivilprozessordnung. URL: https://www.gesetze-im-internet.de/zpo/.

6. Freundschaft-, Handels- und Schiffahrtsvertrag zwischen der Bundesrepublik Deutschland und den Vereinigten Staaten von Amerika vom 29. Oktober 1954. URL: https://www.bgbl.de/xaver/bgbl/start. xav\#_bgbl_\%2F \% 2F $\%$ 5B $\%$ 40attr_id $\% 3 \mathrm{D} \%$ 27bgbl256s0487.pdf $\%$ 27\% 5D_1599394840815

7. Official Journal of the European Union Consolidated versions of the Treaty on European Unionand the Treaty on the functioning of the European Union. Brussels, 09.05.2008, P. 33. URL: https://eurlex. europa.eu/LexUriServ/LexUriServ.do?uri=0J:C:2008:115:0013:0045:EN:PDF

8. Directive (EU) 2019/2121 of the European Parliament and of the Council of 27 November 2019 amending Directive (EU) 2017/1132 as regards cross-border conversions, mergers and divisions (Text with EEA relevance). URL: https://eur-lex.europa.eu/legal-content/en/TXT/?uri=CELEX:32019L2121

9. Case 212/97 Centros [1999] ECR I-01459. URL: https://eur-lex.europa.eu/legal-content/EN/ TXT/?uri=CELEX\% 3A61997CJ0212

10. Case C-208/00 berseering [2002] ECR I-09919. URL: https://eur-lex.europa.eu/legal-content/ EN/TXT/?uri=CELEX\% 3A62000CJ0208\#

11. Case C-106/16 Polbud [2017]. URL: http://curia.europa.eu/juris/celex.jsf?celex=62016CJ0106\& lang $1=$ en\&type $=$ TXT\&ancre $=$

12. OLG M nchen Urteil vom 01.07.2002 - II ZR 380/00. URL: https://dejure.org/dienste/vernetzung/ rechtsprechung?Text=NJW $\% 202002, \% 203539$

13. OLG N rnberg, Beschl. v. 19.6.2013 - 12 W 520/13 Abruf-Nr.: 11106R. URL: https://dejure.org/ dienste/vernetzung/rechtsprechung?Gericht=OLG\% 20N\% FCrnberg\&Datum=19.06.2013\&Aktenzeich en $=12 \% 20 \mathrm{~W} \% 20520 \% 2 \mathrm{~F} 13$

14. KG, Beschluss vom 21.03.2016 - $22 \mathrm{~W} 64 / 15$. URL: https://dejure.org/dienste/vernetzung/recht sprechung?Gericht=KG\&Datum=21.03.2016\&Aktenzeichen $=22 \% 20 \mathrm{~W} \% 2064 \% 2 \mathrm{~F} 15$

15. OLG Frankfurt, 03.01.2017 - $20 \mathrm{~W}$ 88/15. URL: https://dejure.org/dienste/vernetzung/ rechtsprechung?Gericht $=0 L G \% 20$ Frankfurt\&Datum $=03.01 .2017 \&$ Aktenzeichen $=20 \% 20 \mathrm{~W} \%$ $2088 \% 2 \mathrm{~F} 15$

\section{Анотація}

Овечкіна О. С. Вирішення колізійних питань правового статусу юридичних осіб у законодавстві ФРН: сучасний стан та перспективи. - Стаття.

У статті досліджується питання вирішення правових колізій, що зумовлені відсутністю єдиного підходу до регулювання приватноправового статусу юридичних осіб законодавствами сучасних держав. Вирішення питання регулювання приватно-правого статусу юридичних осіб в науці міжнародного приватного права вже традиційно вважають одним із найскладніших, оскільки правові системи держав містять суттєві відмінності в обсязі правоздатності юридичних осіб, регламентації щодо порядку їх створення та функціонування, що призводить до правових колізій. Актуальність дослідження регулювання приватноправового статусу іноземних юридичних осіб у ФРН зумовлюється тим, що юридичні особи України вже традиційно співпрацюють з юридичними особами ФРН, яка є одним із найбільших торгових партнерів України. Встановлено, що Ввідний закон до Німецького цивільного уложення не містить колізійної норми, що визначає правовий статус юридичної особи. Німецькою доктриною та судовою практикою закріплено критерій фактичного (реального) місцезнаходження в разі встановлення особистого закону юридичної особи. Щодо іноземних юридичних осіб, котрі належать до держав, які не є державами-членами СС, німецькими судами застосовується, як правило, критерій фактичного місцезнаходження. Застосування критерію осілості в державах-членах ЄС фактично перешкоджає реалізації принципу свободи заснування, визначеному установчими договорами ЄС, що засвідчує прецедентна практика Суду ЄС. Прецедентне право Суду ЄС змінює принципи, за якими держави-члени мають вирішувати колізійні питання регулювання статусу юридичних осіб. У рамках ЄC з метою подолання проблем, що викликані розбіжностями колізійно-правового регулювання статусу юридичних осіб, здійснюються процеси гармонізації національних законодавств держав-членів з окремих питань правового статусу та діяльності юридичних осіб, а також створення нових організаційно-правових форм юридичних осіб, правовий статус та діяльність яких регулюється правом ЄС. Згідно з Директивою СС 2019/2121 має бути гармонізовано норми законодавств держав-членів ЄС щодо транскордонного перетворення, злиття та поділу товариств з обмеженою відповідальністю.

Ключові слова: статус юридичної особи, критерій інкорпорації, критерій осілості, Європейський Союз, принцип свободи заснування, гармонізація законодавства. 


\section{Summary}

Ovechkina O. S. Resolving conflicting issues of the legal status of legal entities in the legislation of Germany: current status and prospects. - Article.

The article investigates the issue of resolving legal conflicts due to the lack of a unified approach to the regulation of the private status of legal entities by the laws of modern states. Solving the issue of regulating the private status of legal entities in the science of private international law has traditionally been considered one of the most difficult, as the legal systems of states contain significant differences in the legal capacity of legal entities, regulations on their creation and operation, which leads, inter alia, to legal conflicts. The relevance of the study of the regulation of the private status of foreign legal entities in Germany is due to the fact that legal entities of Ukraine have traditionally cooperated with legal entities of Germany, which is one of the largest trading partners of Ukraine. It is established that the Introductory Law to the German Civil Code does not contain a conflict rule that determines the legal status of a legal entity. German doctrine and case law enshrine the criterion of actual (real) location in establishing the personal law of a legal entity. For foreign legal entities belonging to non-EU countries, German courts generally apply the criterion of actual location. The application of the residency criterion in the EU Member States effectively impedes the implementation of the principle of freedom of establishment enshrined in the EU's founding treaties, as evidenced by the case law of the Court of Justice. The case law of the Court of Justice changes the principles according to which Member States must resolve conflicting issues governing the status of legal persons. Within the $\mathrm{EU}$, in order to overcome the problems caused by differences in conflict of law regulation of the status of legal entities, the processes of harmonization of national laws of Member States on certain issues of legal status and activities of legal entities, as well as the creation of new legal forms of legal entities, legal status and whose activities are regulated by EU law. According to EU Directive 2019/2121, the norms of the legislation of the EU member states on cross-border transformation, mergers and divisions of limited liability companies must be harmonized.

Key words: status of a legal entity, criterion of incorporation, criterion of settlement, European Union, principle of freedom of establishment, harmonization of legislation. 